\title{
The impacts of COVID-19 on the environmental sustainability: a perspective from the Southeast Asian region
}

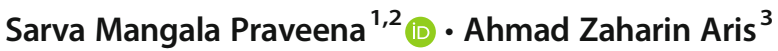 \\ Received: 31 August 2020 / Accepted: 19 November 2020 / Published online: 6 January 2021 \\ (C) Springer-Verlag GmbH Germany, part of Springer Nature 2021
}

\begin{abstract}
This study examined the impacts of the Coronavirus disease 2019 (COVID-19) on the environment in the Southeast Asia region using qualitative content analysis to analyze the textual data of published studies and other online references such as the organizational reports. Besides, the materiality assessment particularly the Global Reporting Initiative was conducted by analyzing short- and long-term impacts from the stakeholders' (local and regional policymakers) perspective. The positive effects of COVID-19 lockdown and movement restriction on the regional environment identified in this study included a reduction in air pollution, improvement of air and water quality, lower noise levels, and reduced land surface temperature. In contrast, the negative effects encompassed a rise in the use of plastics and the generation of medical waste in Indonesia, Malaysia, Thailand, the Philippines, and Vietnam. Materiality assessment findings have offered insights on the need of stakeholders' importance for further to deal with huge amount of waste, inadequate waste management facilities and system, explore the effectiveness of such sustainable work and lifestyle changes, utilize real-time monitoring air quality data and future prediction responses for climate change mitigation and adaptation policies as well as consideration towards new green technologies for clean energy in each Southeast Asian country and at regional level. It is anticipated that this study will contribute towards a better understanding of the impacts of COVID-19 on environmental sustainability in the Southeast Asia region, particularly from the perspective of the stakeholders.
\end{abstract}

Keywords COVID-19 $\cdot$ Impacts $\cdot$ Environment $\cdot$ Sustainability $\cdot$ Southeast Asia

\section{Introduction}

The current worldwide pandemic of the Coronavirus disease 2019 (COVID-19) is the greatest global challenge since World War II. As of the end of May 2020, 117,551 cases have been confirmed globally, with $38 \%$ of cases from Southeast

Responsible Editor: Philippe Garrigues

Sarva Mangala Praveena

smpraveena@upm.edu.my

1 Department of Environmental and Occupational Health, Faculty of Medicine and Health Science, Universiti Putra Malaysia, 43400, UPM, Serdang, Selangor, Malaysia

2 Laboratory of Food Safety and Food, Integrity, Institute of Tropical Agriculture and Food Security, Universiti Putra Malaysia, Serdang, Malaysia

3 Department of Environment, Faculty of Forestry and Environment, Universiti Putra Malaysia, 43400, UPM, Serdang, Selangor, Malaysia
Asia. The COVID-19, caused by the Coronavirus 2, or SARSCoV2 (Chan et al. 2020), is an infectious disease that the World Health Organization (WHO) declared as a global pandemic in March 2020. In human-to-human transmission, the virus spreads directly through close contact via respiratory droplets produced from coughs or sneezes and indirectly through contaminated surfaces such as plastics and stainless steel (Van Doremalen et al. 2020). To date, Indonesia has recorded the highest number of coronavirus cases, and the Philippines has experienced the highest mortality rate in the region (Hirschman 2012; Johns Hopkins Coronavirus Resource Center 2020).

With a growing number of confirmed cases, all Southeast Asian countries have implemented various forms of lockdown and movement restrictions, including restriction on social movement, immediate isolation of positive COVID-19 patients, traveling bans, closure of international and interstate borders, closings of schools and higher learning institutions, and suspension of industrial activities and public transportation, since March 2020. These lockdowns and restrictions 
have forced many developing economies into a recession, generating high debt, increased unemployment, and reduction in manufacturing and service activities throughout Southeast Asia (Loayza and Pennings 2020; Ozili and Arun 2020). Along with the COVID-19 pandemic, increasing attention has been paid to better understand the economics of public health and medical aspects of infectious diseases, including infection peak, hospital admission, and total deaths in Southeast Asia (Setiati and Azwar 2020; Tay et al. 2020). On the other hand, the lockdowns and movement restrictions of the COVID-19 pandemic have also produced various environmental effects in the region. Although these environmental effects were relatively better understood in countries that are most severely affected by the COVID-19 infections, such as China, the United States (US), Italy, and Spain (ZambranoMonserrate et al. 2020), studies in the Southeast Asia region remains scarce and limited to a local scale (Ash'aari et al. 2020; Dang and Trinh 2020; Li and Tartarini 2020; Stratoulias and Nuthammachot 2020; Tosepu et al. 2020). Furthermore, little effort is known to synthesize the localscale findings into an overall understanding of the COVID19 pandemic's impact on the environment in the Southeast Asia region.

Attempts to address sustainability have been growing on both local and global scales, in which various frameworks and guidelines have been developed for sustainability reporting. Among the key principles used in sustainability reporting, the most widely used one is the materiality assessment because it could affect the stakeholder groups' (local and regional policymakers, civil society, industry, researchers) decision to determine the actions to be taken to enhance future environmental sustainability (Torelli et al. 2020). In particular, the Global Reporting Initiative (GRI), which applies the methodology of content analysis, is suitable for studying the sustainability of various sectors, including tourism, construction, mining, and targeting a specific sector or an indicator $(\mathrm{Wu}$ et al. 2018). However, the GRI assessments are more widely used in developed countries such as the US, France, and Sweden, focusing on the accountability of public sectors and corporates for some specific sectors (Moneva et al. 2006; Guthrie and Farneti 2008; Lodhia et al. 2012; Aktas et al. 2013) or a single indicator (Olsthoorn et al. 2001; Searcy et al. 2016) and stakeholders' transparency (FernandezFeijoo et al. 2014; Bradford et al. 2017; Diouf and Boiral 2017). In contrast, the materiality assessment on sustainability is very scarce in developing countries, let alone within a region such as Southeast Asia (Bae et al. 2018; Tarquinio et al. 2018).

Presently, the Southeast Asia region is experiencing various environmental impacts that the COVID-19 pandemic had generated. Therefore, the objective of this study was to develop an overview for a better understanding of the impacts of COVID-19 on environmental sustainability in the region using the materiality assessment, particularly from the perspective of stakeholders (local and regional policymakers). Such an understanding would serve as a reference point for the relevant stakeholders to enhance environmental sustainability in Southeast Asian countries.

\section{Methodology}

The qualitative content analysis was used to analyze the textual data of published studies available on the Internet. The published references for these environmental effects primarily came from scientific databases such as Web of Science, Scopus, and Google Scholar. Other online references such as the organizational reports of the WHO and the World Meteorological Organization, and newspapers were also used largely because there were limited publications of this subject in these scientific databases (Appendix). Multiple searches and screening via various keywords such as Southeast Asia, COVID-19, and environmental effects and sustainability were conducted to capture as many relevant references as possible.

In this study, the impacts of the COVID-19 pandemic on the environment were examined from the perspective of stakeholders' (local and regional policymakers) importance using the GRI method of a materiality assessment. Materiality assessment was conducted using content analysis method to analyze positive and negative environmental effects content extracted from the selected literatures. Then, all the analyzed information was categorized into short- and long-term impacts relevant to Southeast Asia region. Materiality matrix was utilized to visualize these short- and long-term impacts with its importances to stakeholder point of view. Short- and longterm prioritization in materiality matrix will able to provide stakeholders a clear framework for future sustainability decision and actions in each Southeast Asian country and at regional level.

\section{Results and discussion}

As a result of the COVID-19 lockdown and restriction, various positive and negative environmental impacts were recorded in each of the Southeast Asian countries. Most prominent of all, there were noticeable improvements in air quality and transboundary haze pollution within the region. An improvement in air quality was also recorded in other countries worldwide (Kanniah et al. 2020; Zambrano-Monserrate et al. 2020). However, a drastic increase in household plastics and medical wastes were the main negative environmental effect observed in Southeast Asia (Table 1).

In the major urban areas of Indonesia, Malaysia, Singapore, Thailand, the Philippines, and Vietnam, air pollutants such as fine particles, or more commonly known as particulate matter 
Table 1 Environmental effects observed in Southeast Asian countries due to COVID-19

\begin{tabular}{|c|c|c|c|}
\hline $\begin{array}{l}\text { Southeast } \\
\text { Asia } \\
\text { countries }\end{array}$ & Measures taken by the Government & Positive & Negative \\
\hline Brunei & $\begin{array}{l}\text { Measures implemented locally } \\
\text { (travel ban, restrictions on public } \\
\text { gatherings, work from home) }\end{array}$ & No changes in terms of air pollution levels & NA \\
\hline Cambodia & National Emergency Declaration & No changes in terms of air pollution levels & NA \\
\hline Timor-Leste & National State of Emergency & No changes in terms of air pollution levels & NA \\
\hline Indonesia & $\begin{array}{l}\text { Partial shutdown and Large-Scale } \\
\text { Social Restrictions (LSSR) }\end{array}$ & $\begin{array}{l}\text { Improvement of air quality (The Jakarta Post 2020) } \\
\text { Reduction of } 33 \% \text { of } \mathrm{PM}_{2.5} \text { concentrations in Jakarta } \\
\text { (The Jakarta Post 2020) } \\
40 \% \text { drop in } \mathrm{NO}_{2} \text { levels in Jakarta (The Jakarta Post } \\
\text { 2020) }\end{array}$ & $\begin{array}{l}\text { Total of } 247 \text { tonnes per day medical } \\
\text { waste in Jakarta (Asian Development } \\
\text { Bank 2020) }\end{array}$ \\
\hline Laos & Lockdown and Travel Restrictions & No changes in terms of air pollution levels & NA \\
\hline Malaysia & $\begin{array}{l}\text { Movement Control Oder (MCO) } \\
\text { by phases }\end{array}$ & $\begin{array}{l}\text { Decreased concentrations of } \mathrm{PM}_{10}, \mathrm{PM}_{2.5}, \mathrm{NO}_{2}, \mathrm{SO}_{2} \text {, } \\
\text { and CO between } 23 \text { and } 64 \% \text { at industrial, suburban, } \\
\text { and rural sites from urban areas across the country } \\
\text { (Kanniah et al. 2020) } \\
\text { Reduction of } \mathrm{PM}_{2.5} \text { concentrations up to } 58.4 \% \text { during } \\
\text { the MCO in Malaysia (Abdullah et al. 2020) } \\
\text { Improvement of Air Pollutant Index (API) levels } \\
\text { (Raman 2020) } \\
\text { Real-time improvement in river water quality index } \\
\text { (WQI) (Teoh 2020; Raman 2020) } \\
\text { Decreased in total suspended solids and increased in } \\
\text { dissolved oxygen and chemical oxygen demand } \\
\text { (Babulal 2020) } \\
\text { Reduction of land surface temperatures in cities (Raman } \\
\text { 2020) }\end{array}$ & $\begin{array}{l}\text { Waste spillage (Yuen et al. 2020) } \\
\text { Increased household and plastics wastes } \\
\text { (Teoh 2020) } \\
\text { Total production of } 180 \text { tonnes per day } \\
\text { medical waste in Kuala Lumpur } \\
\text { (Asian Development Bank 2020) }\end{array}$ \\
\hline Myanmar & $\begin{array}{l}\text { Community/partial lockdown, } \\
\text { banned gatherings and flights }\end{array}$ & No changes in terms of air pollution levels & NA \\
\hline Singapore & Circuit breaker lockdown & $\begin{array}{l}\text { Increased air quality with decreased } \mathrm{PM}_{10}, \mathrm{PM}_{2.5}, \mathrm{NO}_{2} \text {, } \\
\mathrm{SO}_{2} \text {, and } \mathrm{CO}_{2} \text { between } 8 \text { and } 43 \% \text { (Christopher Tan } \\
2020 \text { ) } \\
\left.30 \% \text { of } \mathrm{NO}_{2} \text { reduction (Kanniah et al. } 2020\right)\end{array}$ & $\begin{array}{l}\text { Increase extra plastics waste of } \\
1334 \text { tonnes (TodayOnline 2020) }\end{array}$ \\
\hline Thailand & Nationwide lockdown & $\begin{array}{l}\mathrm{PM}_{2.5}, \mathrm{PM}_{10}, \mathrm{CO}, \mathrm{NO}_{2} \text {, and } \mathrm{O}_{3} \text { decreased between } 9.7 \\
\quad \text { and } 44.6 \% \text { in general areas in Bangkok (Fatima Arkin } \\
\text { 2020; Jack Board 2020) }\end{array}$ & $\begin{array}{l}\text { Increased on plastic waste volume (The } \\
\text { Japan Times 2020) } \\
\text { Increase food waste and contaminated } \\
\text { medical waste (Jack Board 2020) } \\
\text { Decrease municipal waste in urban } \\
\text { areas (Jack Board 2020) } \\
\text { Total production of } 245 \text { tonnes per day } \\
\text { medical waste in Bangkok (Asian } \\
\text { Development Bank 2020) }\end{array}$ \\
\hline $\begin{array}{l}\text { The } \\
\text { Philippines }\end{array}$ & $\begin{array}{l}\text { Enhanced Community Quarantine } \\
\text { (ECQ) }\end{array}$ & $\begin{array}{l}\text { Reduction of } \mathrm{PM}_{2.5} \text { concentrations up to } 71-80 \% \\
\text { (Fatima Arkin 2020) } \\
34 \% \text { reduction in the } \mathrm{NO}_{2} \text { levels in Manila (Kanniah } \\
\text { et al. 2020) } \\
40 \% \text { decline in the country's power demand }\end{array}$ & $\begin{array}{l}\text { Total production of } 327 \mathrm{t} \text { per day } \\
\text { medical waste in Manila (Asian } \\
\text { Development Bank 2020) }\end{array}$ \\
\hline Vietnam & National lockdown & $\begin{array}{l}\text { Reduced } \mathrm{PM}_{2.5} \text { and } \mathrm{NO}_{2} \text { emissions in Hanoi and Ho Chi } \\
\text { Minh cities (Le 2020; Suarez and Myllyvirta 2020) } \\
\text { Improved AQI levels in Hanoi and Ho Chi Minh (Le } \\
\text { 2020; Suarez and Myllyvirta 2020) } \\
\text { Less noise level (Le 2020) }\end{array}$ & $\begin{array}{l}\text { Total production of } 187 \text { tonnes per day } \\
\text { medical waste in Hanoi (Asian } \\
\text { Development Bank 2020) }\end{array}$ \\
\hline
\end{tabular}

NA not available

$2.5\left(\mathrm{PM}_{2.5}\right)$, carbon monoxide $(\mathrm{CO})$, nitrogen dioxide $\left(\mathrm{NO}_{2}\right)$, sulfur dioxide $\left(\mathrm{SO}_{2}\right)$, and carbon dioxide $\left(\mathrm{CO}_{2}\right)$ were found to have substantially decreased in concentration (citation needed here). Such a decrease was attributable to the social restriction of work from home, which resulted in a drastic decline in the number of vehicles on the road. In Jakarta, the concentrations 
of air pollutants, particularly the $\mathrm{PM}_{2.5}$, were low on rainy days while increasing slightly on sunny days (The Jakarta Post 2020). However, the levels of $\mathrm{NO}_{2}$ remained high in areas with power plants, such as in the province of Banten (Indonesia), whereby the operation of power plants was nonstopping despite the lockdown (Suarez and Myllyvirta 2020).

Also, the reduction of air pollutant concentrations in Malaysia was as much as 64\% (Abdullah et al. 2020; Kanniah et al. 2020), attributable to the more stringent movement control orders (MCO) that temporarily halted most of the anthropogenic activities and industrial operations. The reduction of air pollutant concentrations occurred mostly in industrial and urban areas, which was directly associated with vehicle emissions (Kanniah et al. 2020). Similarly, the air pollutant index values also improved, together with a reduction in land surface temperature, which occurred mostly in urban areas due largely to emission reductions from vehicles and industries (Raman 2020). However, the concentrations of $\mathrm{NO}_{2}$ remained unchanged in areas with coal and gas power plants in Malaysia (Suarez and Myllyvirta (2020), since the power plants operated continually even during the lockdown. In Singapore, air quality improvement was also attributable to the implementation of work from home with a substantial reduction in traffic volume and industrial operations (Tan 2020). However, the reduction in the atmospheric concentration of $\mathrm{NO}_{2}$ in Singapore was much lower than in other Southeast Asian countries because $\mathrm{NO}_{2}$ emissions from major gas-powered plants and shipping terminals continued during the lockdown (Kanniah et al. 2020; Suarez and Myllyvirta 2020).

In Thailand, improved air quality was recorded in Bangkok. Similar to other major cities in Southeast Asia, a reduction of air pollutants, namely $\mathrm{PM}_{2.5}$ and $\mathrm{NO}_{2}$ in Bangkok, was associated with a lower traffic volume with a drastic decrease in the number of vehicles on the road and a reduced operation of heavy industries (Jack Board 2020). However, there were no apparent changes in the concentrations of respirable particulate matters, or $\mathrm{PM}_{10}$, and $\mathrm{NO}_{2}$ in northern Thailand due to continuous agricultural burning, forest fires, persistent dry conditions, and the operation of coal and gas power plants during the lockdown period (Suarez and Myllyvirta 2020). In the Philippines, the concentration of $\mathrm{PM}_{2.5}$ and $\mathrm{NO}_{2}$ decreased by $80 \%$ and $45 \%$, respectively, in Metro Manila, which was also attributed to a decline in the number of motor vehicles on the road during the enhanced community quarantine. In the Philippines, approximately $65 \%$ of the air pollutants were derived from mobile sources, such as cars, motorcycles, and buses. In comparison, $21 \%$ came from stationary sources, such as power plants and factories, and the rest were from open burning (the National Air Quality Status Report 2016).

Also, there was an improvement in the Air Quality Index (AQI) in Hanoi (Vietnam), due to a reduction in the particulate emission of a large number of factories and vehicles. A similar trend was observed in Ho Chi Minh City (Vietnam), with AQI reported at good levels throughout April 2020 (Le 2020). Likewise, a reduction in the concentration of $\mathrm{PM}_{2.5}$ and $\mathrm{NO}_{2}$ was recorded in Hanoi and Ho Chi Minh City. However, outside these cities, the atmospheric concentration of $\mathrm{NO}_{2}$ remained high due to particulate emissions from the continuous operation of the coal-fired power plants (Suarez and Myllyvirta 2020). Although there were no quantitative findings available for Brunei, Cambodia, Laos, Myanmar, and Timor-Leste, it was deduced that there were no changes in the levels of air pollution in these countries (Suarez and Myllyvirta 2020).

Meanwhile, the significant challenges that transboundary haze pollution exerted in Southeast Asia for decades also showed some improvements, particularly in the Mekong sub-region (Fig. 1). In May 2020, only moderate hazes were recorded in the northern parts of Laos, where localized moderate to dense smoke fuming in the Mekong sub-region in a lesser number of days. Improvements in haze pollution in the Mekong sub-region were attributed to various forms of lockdowns, and social movement restrictions, in addition to a gradual increase of rainfall in May 2020 in the northern part of Southeast Asia region due to the Southwest Monsoon season and the prevailing winds shifted to blow from the southeast or southwest of the Southeast Asia region (ASEAN Specialised Meteorological Centre 2020).

Meanwhile, there were also improvements in the river water quality index, i.e., a decrease in the total suspended solids and an increase in dissolved oxygen, which was attributable to a reduction in the total amount of garbage and pollution loadings in Malaysian rivers during the lockdown period (Babulal 2020; Raman 2020).

Other than the positive impacts, the COVID-19 also produced numerous adverse effects on the environment within the region. The foremost negative environmental impact during the pandemic lockdown was the massive generation of plastic waste in Malaysia, Singapore, and Thailand (The Japan Times 2020; Yuen et al. 2020). A fresh pile of plastic waste was generated in Bangkok (Thailand), Kuala Lumpur (Malaysia), and Singapore through a spike in online delivery services, single-use plastic packaging, bags and containers from food deliveries, and demand for sanitizers and bottled water (The Japan Times 2020; TodayOnline 2020). Furthermore, the lockdown period also halted the movement of workers, which resulted in a shortage of solid waste workforce to manage the disposal of plastics and recycling processes (Klemeš et al. 2020).

Given that the COVID-19 virus may be viable for several hours to days on plastic surfaces, the pressure on waste management became further exacerbated (Van Doremalen et al. 2020). Likewise, with an increase in the use of single-use medical equipment, consumable, and protective gear, medical waste also significantly increased in Indonesia, Malaysia, the 
Fig. 2 Stakeholder importance on COVID-19 impacts for sustainability in Southeast Asia region

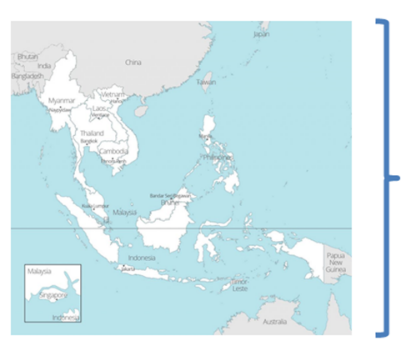

Philippines, and Thailand. With the sudden surge in medical waste, the capacity for Southeast Asian countries to deal with the extra waste would soon be exhausted in light of the inadequate medical and hazardous waste disposal facilities in most of these countries (Asian Development Bank 2020; Fernandes 2020). With limited capacity and financial means to modernize the current medical waste treatment facilities in most Southeast Asian countries, reframing the current medical waste supply chain would probably be the best option for the proper disposal of medical waste in these countries (Fernandes 2020; Peters and Chan 2020; World Health Organization 2020).

\section{Prioritization of COVID-19 impacts on environmental sustainability}

The environmental effects that the COVID-19 lockdowns generated necessitated a much needed transformational change to safeguard the environmental sustainability in the Southeast Asia region. Figure 2 shows the materiality matrix of the short- and long-term impacts on the environment that the COVID-19 pandemic generated from the perspective of stakeholders' importance in the Southeast Asia region.

The short-term impact ranked from the stakeholder importance in the Southeast Asia region was attributed to the huge amount of waste produced during the COVID-19 pandemic lockdown. A surge in medical waste along with household waste, particularly plastic waste, exerted severe challenges to environmental sustainability due largely to inadequate waste management facilities and technology in Southeast Asia countries, such as Indonesia, Malaysia, Thailand, the Philippines, and Vietnam. However, at the same time, this crisis also created an opportunity for these countries to establish an effective and sustainable waste management system to safeguard the environment. Thus, the concerns of stakeholders would be needed to evaluate the various aspects of developing new solid waste management while improving the existing system. In this respect, decentralizing waste management via treatment and recycling appears to be the best way to reduce waste

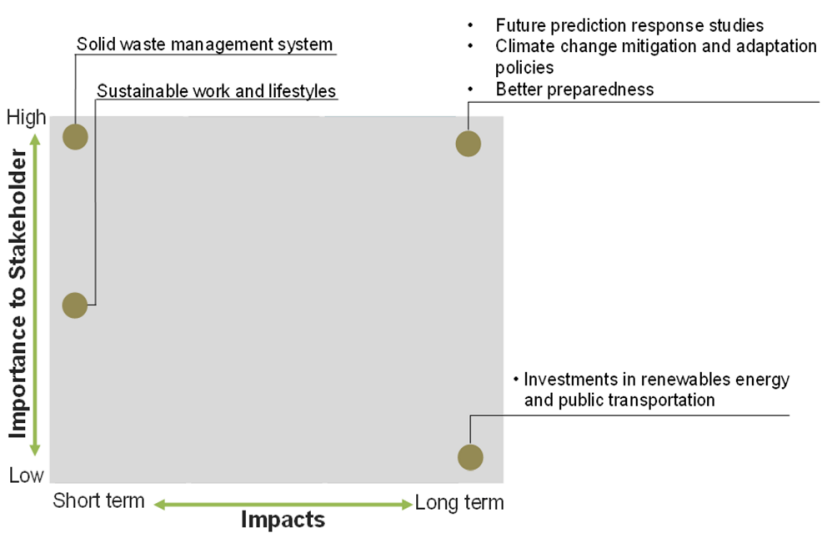

collection and transportation burden (Kulkarni and Anantharama 2020), especially in reducing the operating cost, and lessening the possibility of infection risk among workers. Furthermore, decentralized waste management could easily be adapted to the existing waste management system while increasing the efficiency of recycling (citation needed). However, a further feasibility study is needed to further evaluate the incorporation of decentralized waste management systems into the existing system.

Meanwhile, although the improvement of air quality was deemed as a short-term impact, the concern of stakeholders would still be needed to identify the sustainable solutions for further improving the air quality to a better level upon the disappearance of the pandemic. In this respect, the stakeholders could pledge for a transformational change in work style and lifestyle, such as work from home, remote work, and various activities to be mediated online. These practices had been rapidly implemented worldwide, especially in developed countries. A sustainable work style and lifestyle in the developed countries did not just manage to promote a zero-carbon society; it also promoted a balance between work and quality life (Sarkis et al. 2020). However, the effectiveness of implementing such a change to sustainable work style and lifestyle would need to be carefully evaluated, especially in the areas of economic inequality, technological capabilities, and the relevant policies in developing countries (Hakovirta and Denuwara 2020).

As for the long-term benefit of environmental sustainability, the COVID-19 lockdown provided us with a golden opportunity to collect, monitor, and evaluate various real-time data of greenhouse gases emission, short-term changes in air quality, and meteorological data. This real-time data could be used for future prediction response studies in better preparation at both local and regional levels (Barbier and Burgess 2020). These data were ranked as of high importance to the stakeholders for further motivating policymakers and stakeholders to work together in improving policies in mitigating climate change at both the national and regional levels. These policies might further reinforce the capacity to address 
Fig. 1 Decreased in number of days with moderate to dense smoke haze observed in Southeast Asia region from March 2020 until May 2020. Source: ASEAN Specialised Meteorological Centre (2020)

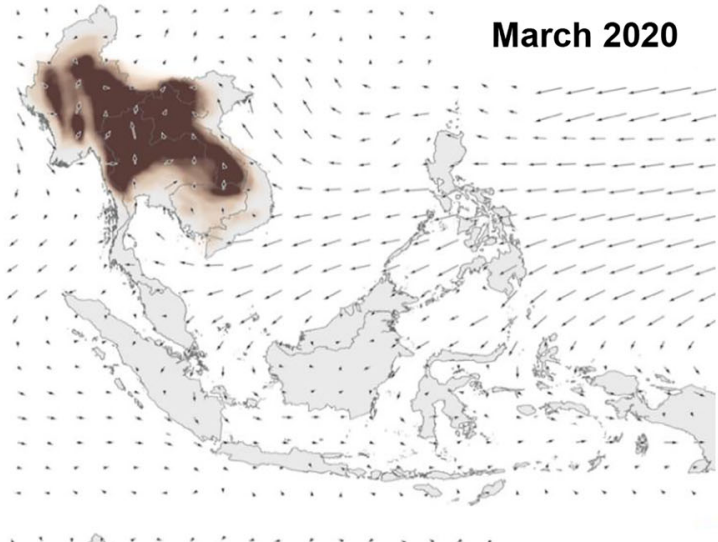

Number of day (s)

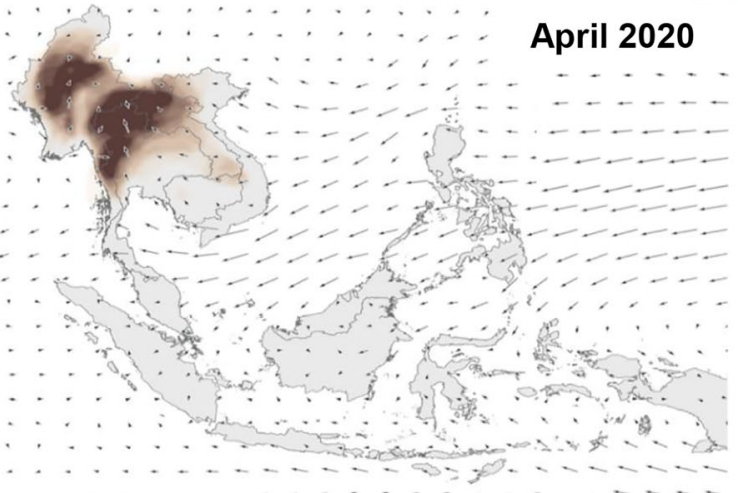

May 2020

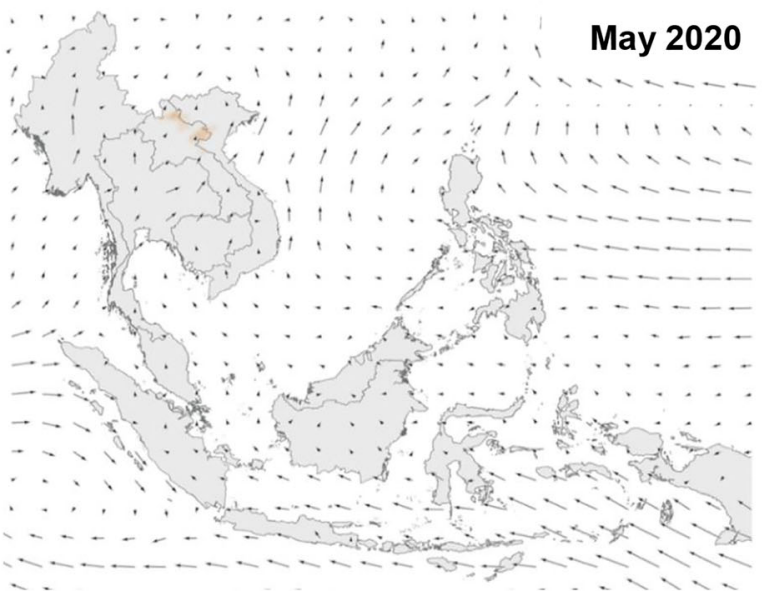

environmental sustainability issues not only in the Southeast Asia region but also globally (Manzanedo and Manning 2020). Besides, the COVID-19 lockdown also decreased the energy demand by the industrial sector while increasing electricity consumption at the household level in most Southeast Asian countries. Currently, investments in renewable energy and public transportation are nearly impossible in Southeast Asia due to the economic recession (Gillingham et al. 2020). However, a modest allocation could be implemented towards the development of new green technologies such as solar energy and hydrogen storage for clean energy with a long-term projection.

\section{Limitations of the study}

Although this study provided an overview of the environmental effects that the COVID-19 pandemic generated and the prioritization of the importance of stakeholders for best sustainable options in the Southeast Asia region, there were several inherent limitations in this study. Given that all the environmental effects were based on information available in scientific databases, there may be some discrepancies in ranking the importance of stakeholders between the deliberation in this study and the reality. Also, there was little information available from countries such as Myanmar, Cambodia, Brunei, Laos, and Timor-Leste, which was essential in assessing the overall environmental impacts in 
this region. Thus, the importance of stakeholder was summarized using information from Indonesia, Malaysia, Singapore, Thailand, the Philippines, and Vietnam. Stakeholder engagement in future materiality assessment would help to better understand the stakeholders' expectations and needs.

\section{Conclusion}

This review provided an overview of the environmental effects due to the COVID-19 lockdown in the Southeast Asia region. The positive environmental effects included a reduction in air pollution, an improvement in air and water quality as well as noise levels, and land surface temperature reductions. In contrast, the negative environmental effects encompassed a drastic increase in plastic and medical waste, which had exerted a severe challenge to environmental sustainability in the region. The short- and long-term impacts requiring the evaluation by stakeholders may be used as an overture or turning point to strengthen the policy requirements for implementing innovative mitigation actions in battling climate change while framing the best solution to safeguard and sustain the environment within the Southeast Asia region.

Supplementary Information The online version contains supplementary material available at https://doi.org/10.1007/s11356-020-11774-0.

Acknowledgments A huge thank you and sincere appreciation to all the frontline courageous heroes-doctors, nurses, police officers, soldiers, cleaners, etc.- - worldwide for putting themselves at risk to save our lives.

Authors' contributions Sarva Mangala Praveena has contributed to the main conceptual idea, study design, and full article writing. Ahmad Zaharin Aris has checked the review connectivity and improved the write-up.

Data availability All data generated or analyzed during this study are included in this published article and its supplementary information files.

\section{Compliance with ethical standards}

Ethics approval and consent to participate Not applicable.

Consent for publication Not applicable.

Competing interests The authors declare that they have no competing interests.

\section{References}

Abdullah S, Abu Mansor A, Mohd Napi NNL et al (2020) Air quality status during 2020 Malaysia Movement Control Order (MCO) due to 2019 novel coronavirus (2019-nCoV) pandemic. Sci Total Environ 729:139022

Aktas R, Kayalidere K, Kargin M (2013) Corporate sustainability reporting and analysis of sustainability reports in Turkey. Int $\mathrm{J}$ Econ Financ 5. https://doi.org/10.5539/ijef.v5n3p113
ASEAN Specialised Meteorological Centre (2020) Haze review for year 2020. Changi Airport, Singapore. http://asmc.asean.org/hazereview-of-regional-haze-situation-for-may-2020. Accessed 8 June 2020

Ash'aari ZH, Aris AZ, Ezani E et al (2020) Spatiotemporal variations and contributing factors of air pollutant concentrations in Malaysia during movement control order due to pandemic COVID-19. Aerosol Air Qual Res 20:2047-2061. https://doi.org/10.4209/aaqr.2020.06.0334

Asian Development Bank (2020) Managine infectious medical waste during the COVID-19 pandemic. https://www.adb.org. Accessed 3 June 2020

Babulal V (2020) Air and water quality improve during MCO. https://www.nst. com.my/news/nation/2020/04/585488/air-and-water-quality-improveduring-mco?fbclid=IwAR0 U fW 7 f2 iRDN 85 rq Gq11n hNEHooBV8GhSnIQYwlSHl_cQW7HSJwXYxQWM. Accessed $\overline{6}$ June 2020. New Straits times

Bae SM, Masud MAK, Kim JD (2018) A cross-country investigation of corporate governance and corporate sustainability disclosure: a signaling theory perspective. Sustain 10. https://doi.org/10.3390/ su10082611

Barbier EB, Burgess JC (2020) Sustainability and development after COVID-19. World Dev 135:105082

Bradford M, Earp JB, Showalter DS, Williams PF (2017) Corporate sustainability reporting and stakeholder concerns: is there a disconnect? Account Horizons 31:83-102. https://doi.org/10.2308/acch-51639

Chan JFW, Yuan S, Kok KH, To KKW, Chu H, Yang J, Xing F, Liu J, Yip CCY, Poon RWS, Tsoi HW, Lo SKF, Chan KH, Poon VKM, Chan WM, Ip JD, Cai JP, Cheng VCC, Chen H, Hui CKM, Yuen KY (2020) A familial cluster of pneumonia associated with the 2019 novel coronavirus indicating person-to-person transmission: a study of a family cluster. Lancet. 395:514-523. https://doi.org/10.1016/ S0140-6736(20)30154-9

Dang, H-A H, Trinh T-A (2020) The beneficial impacts of COVID-19 lockdowns on air pollution : evidence from Vietnam The Beneficial Impacts of COVID-19 Lockdowns on Air Pollution : Evidence from Vietnam. Discussion Paper Series. IZA DP No. 13651

Diouf D, Boiral O (2017) The quality of sustainability reports and impression management: a stakeholder perspective. Accounting, Audit Account J 30: 643-667. https://doi.org/10.1108/AAAJ-04-2015-2044

Fernandes N (2020) Economic effects of coronavirus outbreak ( COVID19 ) on the world economy Nuno Fernandes Full Professor of Finance IESE Business School Spain. SSRN Electron J https://doi. org/10.2139/ssrn.3557504

Fernandez-Feijoo B, Romero S, Ruiz S (2014) Effect of stakeholders' pressure on transparency of sustainability reports within the GRI framework. J Bus Ethics 122:53-63. https://doi.org/10.1007/ s10551-013-1748-5

Gillingham KT, Knittel CR, Li J et al (2020) The short-run and long-run effects of Covid-19 on energy and the environment. Joule:1-5

Guthrie J, Farneti F (2008) GRI sustainability reporting by australian public sector organizations. Public Money Manag 28:361-366. https://doi.org/10.1111/j.1467-9302.2008.00670.x

Hakovirta M, Denuwara N (2020) How COVID-19 redefines the concept of sustainability. Sustain 12:10-13. https://doi.org/10.3390/ su12093727

Hirschman C, Bonaparte S (2012) Population and society in Southeast Asia: a historical perspective.n Linda Williams and Philip Guest, eds. Demography of Southeast Asia. (2012) Southeast Asia Program, Cornell University, Ithaca, New York

Jack Board (2020) Bangkok breathes cleaner air during COVID-19 pandemic and experts want it to last. https://www.channelnewsasia. com/news/asia/covid-19-thailand-bangkok-air-pollution-12674286. Accessed 2 June 2020

Johns Hopkins Coronavirus Resource Center (2020) Southeast Asia Covid-19 tracker. Johns Hopkins Coronavirus Resource Center, 
Johns Hopkins University. https://coronavirus.jhu.edu/us-map. Accessed 4 June 2020

Kanniah KD, Nurul Amalin Fatihah KZ, Kaskaoutis DG, Latif MT (2020) COVID-19' $\mathrm{s}$ impact on the atmospheric environment in the Southeast Asia region. Sci Total Environ 736:139658. https:// doi.org/10.1016/j.scitotenv.2020.139658

Klemeš JJ, Fan Y Van, Tan RR, Jiang P (2020) Minimising the present and future plastic waste, energy and environmental footprints related to COVID-19. Renew Sustain Energy Rev 127:. https://doi.org/10. 1016/j.rser.2020.109883

Kulkarni BN, Anantharama V (2020) Repercussions of COVID-19 pandemic on municipal solid waste management: challenges and opportunities. Sci Total Environ 743:140693

Le J (2020) Vietnam air quality improves thanks to COVID-19. https:// vnexplorer.net/vietnam-air-quality-improves-thanks-to-covid-19a202018944.html. Accessed 3 June 2020. 1-5

Li J, Tartarini F (2020) Changes in air quality during the COVID-19 lockdown in Singapore and associations with human mobility trends. Aerosol Air Qual Res 20:1748-1758. https://doi.org/10. 4209/aaqr.2020.06.0303

Loayza N V, Pennings S (2020) Macroeconomic policy in the time of COVID-19: a primer for developing countries. Research and Policy Briefs,no. 28;. World Bank, Washington, DC

Lodhia S, Jacobs K, Park YJ (2012) Driving public sector environmental reporting. Public Manag Rev 14:631-647. https://doi.org/10.1080/ 14719037.2011.642565

Manzanedo RD, Manning P (2020) COVID-19: lessons for the climate change emergency. Sci Total Environ 742:140563

Moneva JM, Archel P, Correa C (2006) GRI and the camouflaging of corporate unsustainability. Account Forum 30:121-137. https://doi. org/10.1016/j.accfor.2006.02.001

National Air Quality Status Report (2016) National Air Quality Status Report (2008-2015). Department of Environment and Natural Resources Environmental Management Bureau. Quezon City, The Philippine

Olsthoorn X, Tyteca D, Wehrmeyer W, Wagner M (2001) Environmental indicators for business: a review of the literature and standardisation methods. J Clean Prod 9:453-463. https://doi.org/10.1016/S09596526(01)00005-1

Ozili P, Arun T (2020) Spillover of COVID-19: impact on the global economy. SSRN Electron J. https://doi.org/10.2139/ssrn.3562570

Peters S, Chan CP (2020) Proper disposal of medical waste can help us cope with pandemics.https://blogs.adb.org/blog/proper-disposalmedical-waste-can-help-us-cope-pandemics. Accessed 4 June 2020. 4-7

Raman M (2020) Time to treat environmental issues as paramount. https://www.thestar.com.my/opinion/letters/2020/04/23/time-totreat-environmental-issues-as-paramount.

Sarkis J, Cohen MJ, Dewick P, Schröder P (2020) A brave new world: lessons from the COVID-19 pandemic for transitioning to sustainable supply and production. Resour Conserv Recycl 159:104894. https://doi.org/10.1016/j.resconrec.2020.104894

Searcy C, Dixon SM, Patrick Neumann W (2016) The use of work environment performance indicators in corporate social responsibility reporting. J Clean Prod 112:2907-2921. https://doi.org/10.1016/j. jclepro.2015.10.081

Setiati S, Azwar MK (2020) COVID-19 and Indonesia. Acta Med Indones 52:84-89

Stratoulias D, Nuthammachot N (2020) Air quality development during the COVID-19 pandemic over a medium-sized urban area in Thailand. Sci Total Environ 746:141320
Suarez I, Myllyvirta L (2020) COVID19 Lockdowns across Southeast Asia improve air quality - but not everywhere. https:// energyandcleanair.org/covid19-lockdowns-across-southeast-asia/. Accessed 3 June 2020

Christopher Tan (2020) Coronavirus: air quality improves as Singapore slows down under circuit breaker measures. https://www. straitstimes.com/singapore/transport/coronavirus-air-qualityimproves-as-singapore-slows-down-under-circuit-breaker.

Tarquinio L, Raucci D, Benedetti R (2018) An investigation of global reporting initiative performance indicators in corporate sustainability reports: Greek, Italian and Spanish evidence. Sustain 10:. https:// doi.org/10.3390/su10040897

Tay XKK, Kamarul T, Lok WY, et al. (2020) COVID-19 in Singapore and Malaysia: rising to the challenges of orthopaedic practice in an evolving pandemic. Malaysian Orthop J 14:1-10. https://doi.org/10. 5704/MOJ.2007.001

Teoh M (2020) Blue skies, less waste: COVID-19 and the MCO's effects on the environment. https://www.thestar.com.my/lifestyle/living/ 2020/04/22/earth-day-a-wake-up-call-to-lead-more-environmentallysustainable-lives. Accessed 2 June 2020

The Jakarta Post (2020) Jakarta air quality improves as people commute less, rainfall intensifies. https://www.thejakartapost.com/news/ 2020/03/26/jakarta-air-quality-improves-as-people-commute-lessrainfall-intensifies.html. Accessed 2 June 2020

The Japan Times (2020) Plastic piles up in Thailand as virus fight sidelines pollution battle. https://www.japantimes.co.jp/news/2020/05/ 12/asia-pacific/plastic-thailand-coronavirus-pollution/\#. XtTFj54zZao. Accessed 2 June 2020

TodayOnline (2020) Singapore households generated additional 1, 334 tonnes of plastic waste during circuit breaker.https://www. todayonline.com/singapore/singapore-households-generatedadditional-1334-tonnes-plastic-waste-during-circuit-breaker. Accessed 9 June

Torelli R, Balluchi F, Furlotti K (2020) The materiality assessment and stakeholder engagement: a content analysis of sustainability reports. Corp Soc Responsib Environ Manag 27:470-484. https://doi.org/ $10.1002 /$ csr. 1813

Tosepu R, Gunawan J, Effendy DS, Ahmad LOAI, Lestari H, Bahar H, Asfian P (2020) Correlation between weather and Covid-19 pandemic in Jakarta, Indonesia. Sci Total Environ 725:138436. https://doi.org/10.1016/j.scitotenv.2020.138436

Van Doremalen N, Bushmaker T, Morris DH et al (2020) Aerosol and surface stability of SARS-CoV-2 as compared with SARS-CoV-1. $\mathrm{N}$ Engl J Med

World Health Organization (2020) Water, sanitation, hygiene and waste management for the COVID-19 virus. Interim guidance April 2020

Wu SR, Shao C, Chen J (2018) Approaches on the screening methods for materiality in sustainability reporting. Sustain 10:14-16. https://doi. org $/ 10.3390 /$ su10093233

Yuen M, Koh W, Pfordten D (2020) An MCO "side-effect": a breath of fresh air. https://www.thestar.com.my/news/focus/2020/03/29/anmco-side-effect-a-breath-of-fresh-air. Accessed 1 June 2020. Star

Zambrano-Monserrate MA, Ruano MA, Sanchez-Alcalde L (2020) Indirect effects of COVID-19 on the environment. Sci Total Environ 728:138813. https://doi.org/10.1016/j.scitotenv.2020. 138813

Publisher's note Springer Nature remains neutral with regard to jurisdictional claims in published maps and institutional affiliations. 